
\title{
28 Research Square \\ Role of Selective Bioactive Compounds As An Angiotensin Converting Enzyme Inhibitor
}

\section{Huma Khan}

Shoolini University

\section{Tahir Hussain}

University of Houston College of Pharmacy

\section{Monika Kataria}

Guru Jambheshwar University of Science \& Technology

\section{AMIT SETH}

Manipur University

\section{Md Zubbair Malik \\ Jawaharlal Nehru University}

\section{Ashoutosh Dash}

GH Raisoni University

\section{Subhash Chand}

National Institute of Biologicals

MOHD AZHAR KHAN ( $\nabla$ mk.azhar1@gmail.com )

Shoolini University https://orcid.org/0000-0003-2570-8219

\section{Research Article}

Keywords: Systolic blood pressure, Hibiscus sabdariffa, Angiotensin converting enzyme, beta sitosterol, Nitric oxide, Moringa oleifera

Posted Date: September 13th, 2021

DOI: https://doi.org/10.21203/rs.3.rs-830906/v1

License: (1) This work is licensed under a Creative Commons Attribution 4.0 International License. Read Full License 


\section{Abstract}

Hypertension is one of a major reason of mortality and morbidity and it is associated with heart and renal disease. The aim of this study is to find out the antihypertensive role of bioactive compounds from selected medicinal plants targeting ACE molecule which so far is not known. The plants taken in this study were Moringa oleifera, Azadirachta indica, and Hibiscus sabdariffa. The nitric oxide and superoxide scavenging property vary from $39.50 \%$ to $68 \%$ and $37.67 \%$ to $75.50 \%$. respectively. The inhibition of ACE activity was found maximally in methanolic extract of $A$. indica (74 \%), followed by H. sabdariffa (73.4\%), and least in $M$. oleifera $(71.8 \%)$. The bioactive chloroform fraction was characterized for the presence of compound using standard techniques such as LCMS and NMR $\left({ }^{13} \mathrm{C}-\mathrm{NMR}{ }^{1} \mathrm{H}-\mathrm{NMR}\right)$. The results revealed the presence of betasitosterol in M. oleifera, azadiradionolide in A. indica and hibiscitrin in H. sabdariffa. The compounds have shown significant low binding energy for hibiscitrin $(-12.3 \mathrm{kcal} / \mathrm{mol})$, beta-sitosterol $(-11.2 \mathrm{kcal} / \mathrm{mol})$ and azadiradionolide $(-11.3 \mathrm{kcal} / \mathrm{mol})$ indicating the high efficacy of binding on the enzyme. While, binding energy of drug captopril was $-5.6 \mathrm{kcal} / \mathrm{mol} \&$ enalpril $-8.1 \mathrm{kcal} / \mathrm{mol}$ in the same pocket of the ACE molecule. Upon subjecting molecular dynamic simulation results indicated that beta sitosterol complex provided more compactness than the hibiscitrin and azadiradionolide compounds. The current study delivers a new perspective for the drug development against systolic blood pressure regulation and also opens new horizons for considering alternate highly potent drug target for hypertension.

\section{Introduction}

Hypertension or high blood pressure is acknowledged as one of the leading factors for human illness and impermanence. This is a persistent medical condition and is the utmost common life threatening noncommunicable disease (Gavras, 2009). With the rise of urbanization, there is a change in lifestyles such as smoking, lack of physical activity, unhealthy diet, alcohol, which are major risk factors of hypertension (Alwan, 2010). Many antihypertensive agents, which include potassium-sparing diuretics, central a2-adrenergic agonists, peripheral a1-adrenergic antagonists, central/peripheral adrenergic neuronal-blocking agents, diuretics, $\beta$-blockers, calcium-channel blockers, and blockers of the rennin-angiotensin system, such as angiotensin-converting enzyme inhibitors and angiotensin II type 1 receptor blockers are used alone or in combination to treat hypertension. But antihypertensive drugs have many side-effects such as dry cough, muscle cramps, dizziness, extreme tiredness, dehydration, blurred vision, abnormal heart rate, skin rash, hence, the management of hypertension by herbal medicine is an alternative approach (Vardanyan and Hruby, 2017; McLaughlin et al., 1998).

The renin angiotensin system (RAS) is an important regulator of blood pressure and plays a critical role in the pathogenesis of hypertension, renal and cardiovascular disease. The RAS consist of many components including renin, angiotensinogen (AGT), angiotensin converting enzyme (ACE), ACE2, angiotensin subtype2 receptor (AT2R) and angiotensin subtype 1 receptor (AT1R) (Barnaset al., 1997). The ACE (EC 3.4.15.1) converts Ang I to Ang II, and bradykinin to inactive components. The ACE generated potent Ang II peptide excert effect via predominantly activation of AT1R a vasoconstrictor, plays an important role in the pathogenesis of hypertension, suggesting ACE inhibition as a critical target for controlling systolic blood pressure. Consequently, various compounds from medicinal plants had been explored as ACE inhibitors. Eleusine indica

Loading [MathJax]/jax/output/CommonHTML/jax.js ty (Tutor et al., 2018). The Chrysophyllum cainito controls blood 
pressure due to the presence of phenolic compounds (Mao et al., 2015). Quercetin glycoside a predominant bioactive compound present in citrus fruit, buckwheat and onion was reported as a potential ligand of ACE (Muhammad and Fatima, 2015). The occurrence of secondary metabolites i.e. flavonoids, alkaloids, glycosides, lipids and tannins in plant extract reported to play an important role in ACE inhibition (Reddy et al., 2018). Several, in silico studies have also suggested that bioactive compounds from medicinal plants and herbs are potential drugs to target the RAS components including ACE (Khan et al., 2019). Therefore, there is a significant scope to explore the natural compounds as a mediator in controlling blood pressure. The selected plants used in the study were based on literature survey on ethnopharmacology of Moringa oleifera, Hibiscus sabdariffa, and Azadirachta indica. The compounds from Moringa oleifera (Niaziminin-A) (Anwaret al., 2007), H. sabdariffa (Delphinidin-3-sambubioside) (Ojeda et al., 2010), and A. indica (Nimbidin) (Shori and Baba, 2012) were reported to have antihypertensive activity but their mechanism for targeting ACE molecule is unclear. Hence, the aim of this study is to evaluate ACE inhibitory activity of the compounds from these plant extracts.

\section{Material And Methods}

\section{Sample Collection and preparation}

Leaves of Moringa oleifera, Hibiscus sabdariffa, and Azadirachta indica were collected from the campus of Shoolini University, Solan, Himachal Pradesh (India) and verified with the Botanical Survey of India, Dehradun, Uttrakhand (India) for herbarium No: (271, 272 and 276). The plant leaves were washed and sterilized by mercuric chloride $\left(\mathrm{HgCl}_{2}\right)$ and air dried for 4-5 days. Subsequently, leaves were pulverized by pestle motor and used for extract preparation in methanolic solvent by Soxhlet method. The extract was weighed and stored in a tube,

\section{Fractionation Of The Extract}

Ten grams of leaves extracts of Moringa oleifera, Hibiscus sabdariffa, and Azadirachta indica were resuspended in $300 \mathrm{ml}$ lukewarm distilled water and then transferred into a separating funnel. Chloroform (50 ml $x 3$ times) was taken in the separating funnel, observed monitored by mild shaking (1-2 min) and the chloroform fraction was collected. Similar process of fractionation was repetited for n-butanol and ethyl acetate solvents to collect fractions of different polarity by different solvents (Matkowski et al., 2008).

\section{Characterization By Lcms And Nmr}

The LC-MS analysis was carried out on X-Bridge C18 $(2.1 \times 50 \mathrm{~mm}, 3.5 \mu \mathrm{m})$ column fitted to an LC-MS 6320 Ion Trap instrument (Agilent Technologies). A gradient of 50 to $100 \%$ acetonitrile in $25 \mathrm{mM}$ ammonium acetate buffer was used as a mobile phase and the flow rate was set at $0.4 \mathrm{ml} / \mathrm{min}$. Injection volume was $5 \mu \mathrm{l} .{ }^{1} \mathrm{H} \&{ }^{13} \mathrm{C}$ NMR spectra were recorded on $400 \& 100 \mathrm{MHz}$ cryo-magnet spectrometer (Bruker), respectively (Wolfender et al., 2000).

\section{Nitric Oxide (No) Free Radical Scavenging Activity}

In nitric oxide assay, $2 \mathrm{ml}$ of $10 \mathrm{mM}$ sodium nitroprusside in $0.5 \mathrm{ml}$ of phosphate buffer saline was mixed with Loading [MathJax]/jax/output/CommonHTML/jax.js tions $(100-500 \mu \mathrm{g} / \mathrm{ml})$ and the mixture was incubated for $150 \mathrm{~min}$ 
at $23^{\circ} \mathrm{C}$. Of this incubating solution, $0.5 \mathrm{ml}$ was added into $1 \mathrm{ml}$ of sulfanilic acid reagent $(20 \%$ glacial acetic acid) and incubated for $5 \mathrm{~min}$ at $23^{\circ} \mathrm{C}$. Thereafter, $1 \mathrm{ml}$ of Naphthylethylene diamine dihydrochloride was added and incubated for 30 min at room temperature. Absorbance was read at $540 \mathrm{~nm}$ with spectrophotometer (Rao et al., 2016).

The NO radical scavenging activity was calculated according to the following equation: -

$$
\text { \NOinhibitoryactivity }=\frac{A_{o-} A_{S}}{A_{o}} \times 100
$$

Where $\mathrm{Ao}=$ absorbance of the control (blank, without extract); As = absorbance in the presence of the extract.

\section{Superoxide (0) Radical Scavenging Activity}

The superoxide radical scavenging assay was performed as described by Khatua and Acharya, 2016. The 2nM methionine was prepared by dissolving $0.076 \mathrm{gm}$ in $5 \mathrm{ml}$ of distilled water and $0.1 \mathrm{nM}$ EDTA was prepared by $0.004 \mathrm{gm}$ in $10 \mathrm{ml}$ of distilled water. Riboflavin was prepared by $0.004 \mathrm{gm}$ in $5 \mathrm{ml}$ of water and $50 \mathrm{Mm}$ sodium phosphate buffer of $\mathrm{pH}$ 7.8. The reaction was containing $50 \mu$ l of sodium phosphate buffer $(\mathrm{pH}-7.8), 83 \mu \mathrm{l}$ plant extract in various concentrations $(100-500 \mu \mathrm{g} / \mathrm{ml})$, methionine $26 \mu \mathrm{l}$, EDTA $20 \mu \mathrm{l}$, Nitrobluetetrazolium 17 $\mu \mathrm{l}$ and riboflavin $4 \mu \mathrm{l}$. The 96 plate was shaken for 15 seconds and initial absorbance was recorded at $595 \mathrm{~nm}$. The plate was kept under in $15 \mathrm{~W}$ light and kept at room temperature for 10 minutes to start reaction. After the incubation the reading was taken at the $595 \mathrm{~nm}$. Ascorbic acid was used as Positive control in different concentration.

The superoxide radical $\left(\mathrm{O}_{2}^{-}\right)$scavenging activity

$$
\text { \%Superoxide(O2 - ) inhibitoryactivity }=\frac{A_{o-} A_{s}}{A_{o}} \times 100
$$

$\mathrm{Ao}=$ absorbance of the blank without extract (control); As = absorbance in presence of extract.

\section{Angiotensin Converting Enzyme Inhibition Assay}

The inhibition of angiotensin converting enzyme by substrate Hippuryl-histidyl-leucine (HHL) (Sigma- H1635) with benzene sulfonyl chloride and pyridine to convert hippuric acid and histidyl-leucine (Tutor and ChichiocoHernandez, 2018). The positive control used in this method was captopril.

Forty $\mu \mathrm{l}$ of $(100-500 \mu \mathrm{g} / \mathrm{ml})$ plant extract, $20 \mu \mathrm{l}$ of $5 \mathrm{mM}$ Hippuryl-histidyl-leucine (Sigma- H1635) and 20 $\mu \mathrm{l}$ of angiotensin converting enzyme (Sigma A6678) from rabbit lungs were mixed with $40 \mu$ of sodium borate buffer ( $\mathrm{pH}$-8.2) having $0.3 \mathrm{M} \mathrm{NaCl}$. The reaction was start with $15 \mathrm{~min}$ pre-incubation of angiotensin converting enzyme with inhibitor at $37^{\circ} \mathrm{C}$ for establish contact. After incubation, substrate $20 \mu \mathrm{l}$ of $5 \mathrm{mM} \mathrm{HHL}$ was further to start Angiotensin converting enzyme reaction. Then incubated mixture aimed at 30 min at $37^{\circ} \mathrm{C}$ and then experiment was finished by addition $50 \mu \mathrm{l}$ of $1 \mathrm{~m} \mathrm{HCl}$. After this instantaneously by the adding of $100 \mu \mathrm{l}$ pyridine and $50 \mu \mathrm{l}$ benzenesulfonyl chloride to grow the yellow color. Absorbance was taken at $410 \mathrm{~nm}$ using 
The following formula was used to determine percent inhibition:

$$
\text { \%inhibition }=1-\frac{[A-B]}{C} \times 100
$$

\section{A: Absorbance of Inhibited sample \\ B: absorbance of Initial sample \\ C: Absorbance of Uninhibited sample \\ In silico molecular docking analysis}

Crystal structure of C-domain (1086) with resolution $2 \AA$ of Angiotensin converting enzyme was downloaded from RCSB protein data bank (Corradi HR et al., 2016; Natesh R et al., 2003). The format of the crystal structure of enzyme was changed from .pdb to. pdbqt via AutodockTools-1.5.6. The receptors were further modified by adding polar hydrogens and converting to. pdbqt files used for molecular docking analysis (Muhammad and Fatima, 2015). Chemical structure of isolated phyto-constituents found in methanolic leaf extract of Moringa oleifera, Hibiscus sabdariffa, and Azadirachta indica were drawn in chemdraw software where 2 D structures were converted into 3 D structure which were further saved as .pdb files (Kashyap et al., 2017). The files were further optimized and converted to. pdbqt files for molecular docking by Auto Dock tools 1.5.6 (Ghersi D and Singh $M$, 2014). Molecular docking was carried out to evaluate the potential of three compounds against ACE which play an important role in Hypertension. AutoDock Vina achieves a nearly two orders of extent speed-up compared to the other molecular docking software like AutoDock 4 (Hisle et al., 2018; Trott and Olson, 2010). The results of docking are analysed by the association of binding energy with the binding or inhibiting capacity of the ligand for any particular receptor. After docking, the resultant receptor-ligand complexes were generated by UCSF chimera 1.9 which is a highly extensible program for interactive visualization and analysis of molecular structures and docking results to know whether the ligands were bound to active sites of the drug target (Pettersen et al., 2004). The minimum binding energy of bioactive compounds specified potent drug targets for ACE. The best docking compound was selected on the basis of hydrogen bonding with the target. The toxicity of the compounds was predicted by ADME - toxicity (http://Immd.ecust.edu.cn:8000/predict/). The all isolated compounds i.e. beta-sitosterol, hibiscitrin and azardinolide from $M$. oleifera, $H$. sabdariffa, and $A$. indica respectively were used ADME-toxicity server (Khan et al., 2019).

\section{Molecular Dynamic Simulation Analysis}

All the MD simulations was performed using GROMACS (Wang and Chou, 2009; Sheng-Xiang, 2013) BioSimulation package installed in Multi-core enabled Linux Ubuntu system. The force field CHARMM27 (Berendsen, 2005) was used to determine the dynamic behavior and different calculations of proteins (de Souza et al., 1999). The water model SPC216 was used to solvate the system (Angiotensin converting enzyme) and prepare the different using different natural compounds to see the inhibitor of Angiotensin converting enzyme. As a control, MD simulation of $30 \mathrm{~ns}$ was carried in water at $300 \mathrm{~K}$. All atoms of Angiotensin converting enzyme and include compounds Beta-sitosterol, Hibiscitrin and Azadiradionolide were equilibrated in cubic box, having size of approximately $73.3 \times 73.3 \times 73.3 \backslash \mathrm{AA}$. Protein was immersed into water and well 
descent, up to a tolerance of $100 \mathrm{~kJ} \mathrm{~mol}^{-1}$ Each system was energy minimized with steepest descent, up to a tolerance of $100 \mathrm{~kJ} \mathrm{~mol}^{-1} \mathrm{~nm}^{-1}$ to remove all bad contacts. The overall charge on the system was neutralized with addition of cationic and anionic concentration of $\mathrm{Na}^{+} \mathrm{Cl}^{-}$. To run the simulation, based on the size and 3D spatial orientation of protein, the dimension ( $x, y$ and $z$ ) of simulation box was defined. All the systems wer prepared in define box, and protein was placed in centre of box, padded around with water and co-solvents. The steepest-descent algorithm along with conjugate gradient was used for the energy minimization process. The system was equilibrated with two ensemble processes, NVT and NPT. Before we start production run, we have to prepared or established the pre-define condition like $\mathrm{pH}$, Temperature. All these information is encapsulated in NVT, NPT and MD parameter files. These physiochemical conditions play a vital role for protein structural and conformational changes. Once, the system is prepared the system is now ready to run.

\section{Cell Toxicity Mtt Assay}

Baby hamster Kidney (BHK-21) cells were cultured at $37^{\circ} \mathrm{C}$ with $5 \% \mathrm{CO}_{2}$ in $\mathrm{DMEM}$ medium, supplemented with $10 \%$ heat inactivated fetal bovine serum. Remove and discard culture medium and then rinse with PBS for removal of extra medium in flask. Briefly rinse the cell layer with trypsin for 2-3 min and incubate in $\mathrm{CO}_{2}$ incubator for 2-3 min. Trypsin poured is around 2-3ml and take cells out containing trypsin to observe cells whether they are dispersed (de-adhered) or not. Pour FBS to neutralize the effect of trypsin. Add cell to falcon and centrifuge at $1000 \mathrm{rpm}$ for $5 \mathrm{~min}$ to remove debris and get pellet containing cells. Remove supernatant and resuspended pellet in new media. Along the experiments, the cells were monitored by microscopic observation in order to detect any morphological changes. Cells were seeded in triplicate at $10^{4} \mathrm{cells} / 200 \mu \mathrm{L}$ per well in a sterile 96 - well plate. The cells were grown in an incubator $\left(5 \% \mathrm{CO}_{2}\right.$ and $\left.37^{\circ} \mathrm{C}\right)$ for 24 hours. After the first incubation, culture medium was replaced by $15 \mu \mathrm{L}$ of variable concentrations of plant extract $(0.12 \mu \mathrm{g} / \mathrm{mL}-$ $0.97 \mu \mathrm{g} / \mathrm{mL}$ ). The cells were incubated for the second time for 24 hours. After 24 hours 150 ul of cell culture media is removed and replaced by 100 ul of DMSO and further incubated for 15 minutes. After 15 minutes reading was taken at 490nm (Srivastava et al., 2009).

\section{Results And Discussion}

\section{Nitric oxide (NO) free radical scavenging activity and Superoxide $\left(\mathrm{O}_{2}^{-}\right)$radical scavenging activity}

The nitric oxide free radical scavenging assay estimation was done by method described by Parul et al., 2013. Among the plant extracts undertaken the Hibiscus sabdariffa showed percentage inhibition of $68 \%\left(\mathrm{IC}_{50}\right.$ value $317.74 \mu \mathrm{g} / \mathrm{mL})$ followed by the plant extract of Azadirachta indica inhibition of $62 \%$ and $\mathrm{IC}_{50}$ value $(320.7473$ $\mu \mathrm{g} / \mathrm{mL})$, and Moringa oleifera inhibition of $48.50 \%$ ( $\mathrm{IC}_{50}$ value $\left.350.618 \mu \mathrm{g} / \mathrm{mL}\right)$, (Table-1). While the ascorbic acid (positive control) showed inhibition of $73.50 \%$ ( $\left(\mathrm{C}_{50}\right.$ value $302.222 \mu \mathrm{g} / \mathrm{mL}$ ) (Figure-1 and Table- 1$)$. Based on the free radical scavenging activity the $\mathrm{IC}_{50}$ value of Hibiscus sabdariffa $(317.74 \mu \mathrm{g} / \mathrm{mL})$ were observed closed to $\mathrm{IC}_{50}$ of positive control $(302.222 \mu \mathrm{g} / \mathrm{mL})$. The need of the hour is to harness and explore novel plant sources having appreciable bioactivity against NO radical accumulation and the accompanying inflammatory reaction. In the present work, Azadirachta indica and Moringa oleifera display higher NO free radical scavenging activity as compared to Hibiscus sabdariffa. One of the main enzymes involved in NO production 
spectrophotometrically at $595 \mathrm{~nm}$. The variations in optical density give a fair assessment of the NO scavenging potency of diverse plant extracts. The phytochemical profile of these plant extracts exhibited the presence of flavanoids and phenolic compounds which are important phytobioactives known for their appreciable radical scavenging potential (Kaurinovic and Vastag, 2019). All the three plants analyzed in the present investigations demonstrate ample NO free radical eradication ability and thus exemplify their intrinsic medicinal potential. Superoxide radicals play a key role in signal transmission at the cellular level (Luis et al., 2018). However, their production beyond a certain threshold in cells has proven to be counterproductive (Basu and Hazra, 2006). This ultimately produces a deleterious effect on biomolecules like proteins, lipids and nucleotides (Engwa, 2018). The most potent superoxide inhibitor proved to be Moringa oleifera followed closely by Azadirachta indica. These plants were traditionally incorporated in folk medications and hence it becomes imperative to prepare a comprehensive biochemical and antioxidant profile so as to harness their antioxidative stress release potential. These plants also displayed higher radical scavenging activity than the positive control used in these experiments. This further underscores the superoxide radical neutralization effect of these medicinal plants capable enough to prevent cell damage. A wide variety of superoxide scavenging phytoconstituents have been identified and characterized which include mangiferin, naringin, quercitin, myticetin among others (Septiana et al., 2010). The elucidation of optimum concentration of these natural superoxide deradicalizers is a key aspect in their use as efficient therapeutic agents.

\section{LC-MS analysis of active Fractions of Moringa oleifera, Azadirachta indica, and Hibiscus sabdariffa}

While doing the LC-MS analysis of the isolated molecule from chloroform fraction of Moringa oleifera, we found a peak of $274 \mathrm{~m} / \mathrm{z}$ in the mass spectrum (Figure 2). Which was assumed to be a fragmentation of betasitosterol $414 \mathrm{~m} / \mathrm{z}$. Hence, the primary conformation of the isolated molecule was beta sitosterol $(414 \mathrm{~m} / \mathrm{z})$. For further conformation we have done ${ }^{1} \mathrm{H}-\mathrm{NMR}$ and ${ }^{13} \mathrm{C}$-NMR.

${ }^{1} \mathrm{H}-\mathrm{NMR}$ and ${ }^{13} \mathrm{C}$-NMR spectra were done using $\mathrm{CDCl}_{3}$ as solvent on Bruker Advance II 400 NMR spectrometer at the department of Pharmacy at Guru Jambeshwar University Hisar, Haryana. The ${ }^{1} \mathrm{H}$-NMR spectrum of compound varied between $\delta 0.5$ to $1 \mathrm{ppm}$. This spectrum shown fifteen protons on carbon $\mathrm{C}_{18}, \mathrm{C}_{21}, \mathrm{C}_{26}, \mathrm{C}_{27}$ and $\mathrm{C}_{29}$ position in the compound structure (Supplementary Figure -1 and Table-1). proton signal between $\delta$ 2.6-4.2 ppm at $\mathrm{C}_{4}, \mathrm{C}_{7}, \mathrm{C}_{25}$ and 1.2 to $2.5 \mathrm{ppm} 47$ proton present at different-different carbon position. Chemical shift of $\delta 5.3$ corresponds to oleifinic proton. ${ }^{13} \mathrm{CNMR}$ spectrum of Compound (1) shows signal at $\mathrm{C}_{3} \beta$ hydroxyl group 17.064 and 11.0 for angular methyl carbon atoms for $C_{19}$ and $C_{18}$ respectively. The $C_{5}, C_{6}, C_{22}$ and $\mathrm{C}_{23}$ appeared to be alkene carbons. The value at $17.064 \mathrm{ppm}$ corresponds to angular carbon atom $\left(\mathrm{C}_{19}\right)$. Spectra show twenty-nine carbon signal including six methyls, nine methylenes, eleven methane and three quaternary carbons (Supplementary Figure-2 and Table-2).

While doing the LC-MS analysis of the chloroform fraction of Azadirachta indica, we found a peak of 425.19 $\mathrm{m} / \mathrm{z}$. Which was assumed to be a fragmentation of Azadiradionolide $\mathrm{m} / \mathrm{z} 480.574 \mathrm{~g} / \mathrm{mol}$. The Moringa oleifera compound i.e. beta sitosterol, similar to cholesterol was also found in fungi, animal and plants. Beta- sitosterol belong to phytosterol which play role in heart disease, antioxidant, diabetes. These are mainly found in the mixture of stigmasterol. The difference between $\beta$ - sitosterol and stigmasterol is single bond and double bond respectively. Study done by Pierre et al., (2015) found $\beta$-sitosterol from Odontonema strictum. Hence, the Loading [MathJax]/jax/output/CommonHTML/jax.js 
primary conformation of the isolated molecule was Azadiradionolide, which was $425.19 \mathrm{~m} / \mathrm{z}$ (Figure-3) (274 $\mathrm{m} / \mathrm{z}$ ). The ${ }^{1} \mathrm{H}$ NMR spectrum of compound varied between $\delta 0.5$ to 1.75 showed the 15 proton at $\mathrm{C}_{18}$ and $\mathrm{C}_{19}$ methyl group carbon (supplementary file Figure-3 and Table-3). In $\delta 2.30$ ppm shown 7 protons at $C_{6}, C_{9}, C_{11}$ and $\mathrm{C}_{12}, \delta 3.72$ shown 3 protons, $\delta$ 3.30-7.55 shown 8 protons at $\mathrm{C}_{17}, \mathrm{C}_{23}, \mathrm{C}_{15}, \mathrm{C}_{2}, \mathrm{C}_{1}$ and $\mathrm{C}_{21}$ (supplementary file Figure-4 and Table-4).

The LC-MS analysis of the chloroform fraction of Hibiscus sabdariffa, we found a peak of $274.25 \mathrm{~m} / \mathrm{z}$. Which was assumed to be a fragmentation of Hibiscitrin m/z 496.377g/mol (Figure-4). As the molecule was peak of Hibiscitrin after fragmentation is $274.25 \mathrm{~m} / \mathrm{z}$ (Figure-4). By ${ }^{1} \mathrm{HNMR}$ analysis $\delta$ 1.01-1.47 ppm shown 12 protons at $\mathrm{C}_{26}, \mathrm{C}_{27}, \mathrm{C}_{28}$ and $\mathrm{C}_{31}$ and $\delta$ 2.3- 2.8 shown 4 protons at $\mathrm{C}_{23}, \mathrm{C}_{24}$ and $\mathrm{C}_{25}$ (supplementary file Figure-5 and Table-5). At $\delta$ 3.68-7.28 ppm shown also shown 4 protons at $\mathrm{C}_{13}, \mathrm{C}_{6}$ and $\mathrm{C}_{23}$. Methylene group shown at $\mathrm{C}_{28}$ (Figure-6 and Table-6).

\section{Angiotensin converting Enzyme Inhibitory Assay}

The six plants extract under this study subjected to ACE inhibitory activity. The percentage inhibition of Azadirachta indica, Hibiscus sabdariffa, Moringa oleifera, Punica granatum, and Allium sativum were showed $74.00 \pm 0.7937 \%, 73.47 \pm 1.434 \%$, and $71.80 \pm 2.650 \%$, (Figure-5). The lowest $I_{50}$ activity were showed by Azadirachta indica $(255.991 \mu \mathrm{g} / \mathrm{ml})$ followed by Hibiscus sabdariffa $(267.722 \mu \mathrm{g} / \mathrm{ml})$, and Moringa oleifera $(294.397 \mu \mathrm{g} / \mathrm{ml})$ (Table-2). Among them based on the $\mathrm{IC}_{50}$ the following plants extracts (Azadirachta indica, Hibiscus sabdariffa, and Moringa oleifera) were used for fractionation. The Azadirachta indica fraction i.e. $n$ - butanol, ethyl acetate and chloroform showed the percentage inhibition and $\mathrm{IC}_{50}$ value were $42.45 \pm 1.050 \%$ ( $\mathrm{IC}_{50}$ value $\left.508.5438 \mu \mathrm{g} / \mathrm{mL}\right), 53.25 \pm 1.750 \%\left(\mathrm{IC}_{50} 373.0502\right.$ value $\left.\mu \mathrm{g} / \mathrm{mL}\right)$, and $68.45 \pm 0.550 \%$ $\left(\mathrm{IC}_{50}\right.$ value $\left.264.4097 \mu \mathrm{g} / \mathrm{mL}\right)$ respectively. The Hibiscus sabdariffa fraction i.e. $\mathrm{n}$ - butanol, ethyl acetate and chloroform showed the percentage inhibition and $\mathrm{IC}_{50}$ value were $28.67 \pm 1.167 \%\left(\mathrm{IC}_{50}\right.$ value $\left.550.3377 \mu \mathrm{g} / \mathrm{mL}\right)$, $47.17 \pm 1.424 \%\left(\mathrm{IC}_{50}\right.$ value $\left.340.875 \mu \mathrm{g} / \mathrm{mL}\right)$, and $62.63 \pm 1.660 \%\left(\mathrm{IC}_{50}\right.$ value $\left.304.246 \mu \mathrm{g} / \mathrm{mL}\right)$ respectively. The Moringa oleifera fraction i.e. n- butanol, ethyl acetate and chloroform showed the percentage inhibition and $\mathrm{IC}_{50}$ value were $32.00 \pm 0.981 \%\left(\mathrm{IC}_{50}\right.$ value $\left.461.9108 \mu \mathrm{g} / \mathrm{mL}\right), 43.57 \pm 0.263 \%\left(\mathrm{IC}_{50}\right.$ value $\left.338.2692 \mu \mathrm{g} / \mathrm{mL}\right), \mathrm{and}$ $58.50 \pm 0.458 \%\left(\mathrm{IC}_{50}\right.$ value $\left.296.7497 \mu \mathrm{g} / \mathrm{mL}\right)$ respectively. The percentage inhibition and $\mathrm{IC}_{50}$ of positive control (captopril) was $81.13 \pm 0.753 \%\left(\mathrm{IC}_{50}\right.$ value $\left.203.2158 \mu \mathrm{g} / \mathrm{mL}\right)$ (Figure-5). Among those fractions the chloroform fractions showed best inhibition activity. Tutor JT and Chichioco-Hernandez CL, 2018 worked on plant extract and ethyl acetate fraction of Eleusine indica and calculated percentage inhibition is $68.84 \%$ and $51.51 \%$ respectively. In our study n-butanol, ethyl acetate, chloroform fraction and extract of $A$. indica shows $30.8 \%, 45.5 \%, 63.9 \%$ and $67.0 \%$ inhibition respectively. The positive control captopril shows $76.0 \%$ inhibition for ACE. Deo et al., 2016 and Khan et al., 2019 reported that the 50\% inhibition of enzyme by plant extract and fraction consider is active.

ACE is a significant enzyme playing a critical role in regulation of blood pressure. Various plant constituents have the ability to inhibit the action of ACE. The active site of ACE is influenced by the phytochemicals present in neem plant. Flavonoids, terpenoids and phenolic compounds have the ability to forge chemical bonds with the amino acids present in close proximity with the active centre of ACE. These new chemical interactins tend Loading [MathJax]/jax/output/CommonHTML/jax.js of ACE thus causing inhibition. Since ACE is a metalloenzyme 
having zinc atom at its active site, a majority of hydrogen bonds and chemical bridges involve not just conserved amino acids of the active site but also zinc atom (Yusuf et al., 2000). In this study the ACE inhibiting compound is identified as azadiradionolide. It is a terpenoid comprising multiple rings. The tetracyclic nature of azadiradionolide is responsible for high ACE inhibitory activity of neem extract. The presence of carbonyl, lactones and methyl groups in azadiradionolide is responsible for enhancing the potency of neem plant extract against ACE. These chemical groups may be acting as causative chelating agents for the zinc atom located at the nerve centre of ACE. The in silico studies reveal that azadiradionolide due to its unique structure is able to gain access into the active site of ACE, establish chemical interactions simultaneously with amino acids and zinc atom and causing alterations in the 3-D structure of catalytic protein thus proving to be a successful ACE inhibitor.

\section{In silico study of antihypertensive bioactive compounds against Renin angiotensin components}

The in silico study is based on the lock and key theory for drug design. This is used for check the biological activity of the natural and synthetic compound and it is time consuming, reasonably and accurate method. The docking of the ligand and enzyme was done by autodock vina software and visualize the hydrogen bonding by chimera and PyMOL. The hydrogen bonding of enzyme and ligand is the important aspect for ligand and enzyme complex formation. In the present study natural isolated compounds targeted the ACE enzyme which has a role in blood pressure regulation. The Angiotensin-converting enzyme converts angiotensin I to angiotensin II a potent peptide hormone exerts its effect predominantly via AT1R (Donoghue et al., 2000). The bioactive molecule reduces the action of angiotensin converting enzyme and control the systolic blood pressure. The fractions of the selected plants were subjected to LCMS and ${ }^{1} \mathrm{H}-\mathrm{NMR}$ and ${ }^{13} \mathrm{C}$ NMR and following compounds were analyzed. Beta- sitosterol was determined in chloroform fraction of Moringa oleifera, Azadiradionolide was determined in chloroform fraction of Azadirachta indica and Hibiscitrin found in chloroform fraction of Hibiscus sabdariffa. All three compounds were docked with one of the major cascade renin angiotensin component i.e. angiotensin converting enzyme. The compounds i.e Hibiscitrin, betasitosterol, and azadiradionolide were showed very low binding energy i.e. $-12.3 \mathrm{kcal} / \mathrm{mol},-11.2 \mathrm{kcal} / \mathrm{mol}$ and $-11.3 \mathrm{kcal} / \mathrm{mol}$ binding energy with ACE crystal structure respectively. The standard drugs are used in this study is captopril and enalpril which shown $-5.6 \mathrm{kcal} / \mathrm{mol}$ and $-8.1 \mathrm{kcal} / \mathrm{mol}$ binding energy with ACE. The Hibiscitrin compound was interacting with six amino acid residues i.e. Asn-263, Gly-254, Thr-358, His-331, Tyr-498, Lys489 (Table-3, Table-4). This Hibiscitrin compound shown hydrophobic interaction with ten amino acid residues i.e. His 491, Ala322, Gln 259, Asp255, Thr 144, Glu 262, Glu 431, Ser 357, Phe 435, Phe 505. The beta-sitosterol shown hydrophilic interaction with Asn 145, Gly 254 and Thr 144 and hydrophobic interaction with Thr 352, Asp 255, Asp 340, Leu 139, His 331, GIn 355, and Asp 354 amino acids residues. The compound isolated from neem i.e. azadiradionolide has shown hydrophilic interaction with Asn 145, Asn 263, Thr 144 and hydrophobic interaction Asp 354, Gly 254, Ala 148, Asp 255, Leu 147, Leu 139, Asp 140, His 331, Gln 355, and Thr 352 amino acid residues. It can be observed that compounds Hibiscitrin a greater number of hydrogen bond interactions with various amino acid residues of the Angiotensin converting enzyme residues. We believe that these hydrogen bond interactions play an important part in the inhibition of the Angiotensin converting enzyme residues, and ultimately better anti-inflammatory activity of the compounds Hibiscitrin (Figure-6). An overlay of the docked pose of Azadiradionolide and Beta-sitosterol also exhibited that these compounds are superimposable with each other (Figure-7, Figure-8.). This indicates that the active site of the Angiotensin Loading [MathJax]/jax/output/CommonHTML/jax.js ate these compounds, which synergizes the Angiotensin 
converting enzyme residues inhibitory activity of the compounds Azadiradionolide and Beta-sitosterol. All these three compounds have shown better binding affinity in comparison to standard drugs (captopril and enalpril). Further these compounds are used for toxicity of the molecule by ADMETSAR software. The toxicity of the compound is the main reason of drug failure in the drug development field (Table-5).

\section{Molecular Dynamic Simulation Study}

MD simulation study has been also executed to investigate the conformational stability of Beta-sitosterol, Hibiscitrin and Azadiradionolide in active site of Angiotensin converting enzyme in water at $300 \mathrm{~K}$. To examine the structural stability of Angiotensin converting enzyme and complex with beta-sitosterol, hibiscitrin and Azadiradionolide. We monitored the time evolution plot of all atom RMSD, Rg, RMSF and SASA. In the fourth parameter the angiotensin converting enzyme with beta sitosterol complex has shown a reduced SASA from $310 \mathrm{~nm}^{2}$ to $285 \mathrm{~nm}^{2}$ up to $5 \mathrm{~ns}$. The solvent accessibility surface area for the of angiotensin converting with beta sitosterol complex indicated a more compact size at the end of the simulation period. SASA. In this case of hibiscitrin (depicted in green), was reduced from $310 \mathrm{~nm}^{2}$ to $290 \mathrm{~nm}^{2}$ and in the case of azadiradionolide reduced from $310 \mathrm{~nm}^{2}$ to $280 \mathrm{~nm}^{2}$. This indicates that beta sitosterol complex will provide more compactness than the hibiscitrin and azadiradionolide, and aromatic ring has less exposed the later on complex. We have detected that complex of protein and compounds shows relatively higher SASA value than wild type protein this could be explain by the presence of relatively larger hydrophobic packed core region in native protein as compare to protein compound complex. In one such similar studies these parameters (RMSD, Rg, SASA and RMSF) were studied by Fang et al., (2019) for ACE that support that support our study.

\section{Radius of gyration}

Another important parameter, radius of gyration $\left(R_{g}\right)$ is used to determine the dynamic adaptability of A CE in water and three different compounds which namely, beta sitosterol, hibiscitrin and azadiradionolide. A time evolution $R_{g}$ plot of backbone atoms (Figure-9 A) shows that the native conformation of ACE is retained in water $R_{g}$ trajectory in water (Black) quickly achieves the stable equilibrium in few nanoseconds. The average $\mathrm{R}_{\mathrm{g}}$ values of $2.37 \pm 0.01 \mathrm{~nm}$ is maintained throughout the simulation period. In the presence of beta sitosterol (depicted in red), $298 \mathrm{~K}$ temperature, the system is decreased in the fluctuation of trajectory is suggested that initial compaction in structure with comparison to water (depict in black) an average value is $2.31 \pm 0.02$. while the previous condition is remaining same and only change the compound instead of Beta sitosterol to used hibiscitrin (depicted in green). Now, the system is gradually increase the fluctuation throughout the simulation relatively less stable than Beta sitosterol, and the average $R_{\mathrm{g}}$ values of $2.34 \pm 0.04$ which indicates a less stable structure and system is expanded. In the presence of Azadiradionolide, $298 \mathrm{~K}$ temperature, the Angiotensin converting enzyme is more stabilized than other three compounds. In $\mathrm{R}_{\mathrm{g}}$ trajectory of Azadiradionolide (Blue line) depicted that quickly achieves stability at $5 \mathrm{~ns}$ and system remain stable and the average $\mathrm{R}_{\mathrm{g} \text { values }}$ of 2.28 \pm 0.01 . nrg for native protein is comparatively more than protein compound complex. The Rg results shows that native protein was more compact after the binding of compound.

\section{Root means square distance (RMSD)}


RMSD are calculated as a function of time, with respect to the initial conformation and its shown in Figure-9 B. Visual inspection of this plot show that Angiotensin converting enzyme in water (black) is unstable during the 0-10 ns time interval and after 10-30 ns system have attained the equilibrium is maintained till the end of simulation of $30 \mathrm{~ns}$. Addition of in the presence of Beta sitosterol (depicted in red), $298 \mathrm{~K}$ temperature to the system resulted in structural perturbation is slightly come into picture at time $0-10$ ns which is relatively more than water and the simulation end up with an increase in RMSD of $\sim 0.012 \mathrm{~nm}$ as compare to native condition. The remaining condition is remain intact only compound is change Hibiscitrin (depicted in green) the morphology of structure is change more than Beta sitosterol and the system remain unstable during the entire time evolution of simulation. The presence of azadiradionolide (depicted in blue) at $298 \mathrm{~K}$ temperature, the ACE in presence of azadiradionolide the system is unstable during the 0-10 ns time interval and after 10-30 ns system. While the behavior of morphology is in between the Beta sitosterol and Hibiscitrin.

\section{Root means square fluctuation (RMSF)}

To capture the dynamics progression of Angiotensin converting or flexibility of structure in water and three different complex with compounds of the Beta-sitosterol (depicted in red), Hibiscitrin (depicted in green) and are Azadiradionolide (depicted in blue) are depicted in Figure-10 A. RMS fluctuations showed that the most flexible residues 291-301, 338-354 are located in loop regions and 324-347 are located in the loop regions, which connect the Beta-sheets to alpha-helices. RMS fluctuation is more in the of Angiotensin converting +Azadiradionolide (depicted in blue) complex compared to the protein +beta sitosterol (depicted in red) complex. Comparatively, Angiotensin converting +Hibiscitrin (depicted in green) showed high fluctuations at 53-65, 66-144, 145-192 positions, these amino acids mostly constituting the loop region, alpha helices played no role in Azadiradionolide (depicted in blue) binding.

\section{Solvent accessible surface area (SASA)}

The SASA for Angiotensin converting + water (in depicted black colour) was $190 \mathrm{~nm}^{2}$ at the beginning of the simulation and retained the area throughout the simulation period shown in the Figure $10 \mathrm{~B}$ Which is quite stable, apart from this addition of in the presence of Beta sitosterol (depicted in red), $298 \mathrm{~K}$ temperature to the system the solvent accessible surface area (SASA) for Angiotensin converting + beta sitosterol was observed to be $310 \mathrm{~nm}^{2}$ at the start of simulation; as dynamics proceeded, it continuously decreased to $285 \mathrm{~nm}^{2}$. The Angiotensin converting + beta sitosterol complex has shown a reduced SASA from $310 \mathrm{~nm}^{2}$ to $285 \mathrm{~nm}^{2}$ up to 5 ns.

The solvent accessibility surface area for the of Angiotensin converting + beta sitosterol complex indicated a more compact size at the end of the simulation period. SASA. In this case of Hibiscitrin (depicted in green), was reduced from $310 \mathrm{~nm}^{2}$ to $290 \mathrm{~nm}^{2}$ and in the case of azadiradionolide reduced from $310 \mathrm{~nm}^{2}$ to $280 \mathrm{~nm}^{2}$. This indicate that beta sitosterol complex is provide more compactness than the Hibiscitrin and azadiradionolide, and aromatic ring has less exposed the later on complex. We have detected that complex of protein and or compounds shows relatively higher SASA value than wild type protein this could be explain by the presence of relatively larger hydrophobic packed core region in native protein as compare to protein 


\section{Cell toxicity assay}

To determine the optimum concentration of the fractionated compounds for biological assays the cell toxicity was determined by MTT assay. The chloroform fraction containing predominantly beta-sitosterol, Hibiscitrin and azadiradionolide compounds were subjected to MTT assay on BHK-21 cell lines. The results revealed that with the treatment of bioactive fraction bearing hibiscitrin (HS) compound showed $99.34 \%$ viability at $970 \mathrm{ug} / \mathrm{ml}$ followed by beta sitosterol (BS) with $99.13 \%$ viability at $970 \mathrm{ug} / \mathrm{ml}$ and azadiradionolide (AZ) with $98.67 \%$ viability at $970 \mathrm{ug} / \mathrm{ml}$. Thus, results indicated that these compounds were least toxic to the cells, further suggesting these compounds are biocompatible and can be utilized as a drug (Figure-11). The Nemudzivhadi and Masoko (2014) showed the $90 \%$ cell viability of bioactive compound from Ricinus communis. In another study by Raiola et al., (2016) found the $80 \%$ cell viability on HEK- 293 cell lines by the extract of tomatoes which is lower from the present study. In support to our findings Arevalo et al., (2018) found $50 \%$ cell viability by the extract of $M$. oleifera and $A$. indica on MDCK cell lines.

\section{Summary}

The present study suggested the consideration of medicinal plants of Himachal Pradesh for targeting the role in hypertension. The isolated and characterized bioactive molecule from Moringa oleifera, Hibiscus sabdariffa and Azadirachta indica were found to be beta-sitosterol, hibiscitrin and azadiradionolide respectively. The most potent molecule to inhibit the ACE of these was hibiscitrin. So this compound could play a significant role in inhibiting the conversion of angiotensin I to angiotensin II to control the systolic blood pressure. The current study delivers a new perspective for the drug development against systolic blood pressure regulation and also opens new horizons for considering alternate highly potent drug target for hypertension.

\section{References}

1. Agrawal DP (2001) Medicinal properties of neem: new findings. History of Indian science and

2. Al Disi SS, Anwar MA, Eid AH (2016) Anti-hypertensive herbs and their mechanisms of action: part I. Frontiers in pharmacology. Jan 19:6:323

3. Al-Hashemi ZS, Hossain MA. Biological activities of different neem leaf crude extracts used locally in Ayurvedic medicine. Pacific Science Review A: Natural Science and Engineering. 2016 Jul 1;18(2):128 31

4. Biswas K, Chattopadhyay I, Banerjee RK, Bandyopadhyay U (2002) Biological activities and medicinal properties of neem (Azadirachta indica). CURRENT SCIENCE-BANGALORE-. Jun 10;82(11):1336-45

5. Cooper R. McFarlane-Anderson N, Bennett Fl, Wilks R, Puras A, Tewksbury D, Ward R, Forrester T (1997) $A C E$, angiotensinogen and obesity: a potential pathway leading to hypertension. $J$ Hum Hypertens 11:107-111

6. Corradi HR, Schwager SL, Nchinda AT et al (2006) Crystal structure of the N domain of human somatic angiotensin l-converting enzyme provides a structural basis for domain-specific inhibitor design. J Mol Biol 357:964-974

7. Delmondes P, Benício R. In silico study of the natural compounds inhibiting angiotensin converting onzivma ll 2017

Loading [MathJax]/jax/output/CommonHTML/jax.js

Page $12 / 25$ 
8. Elbl G, Wagner $\mathrm{H}$. A new method for the in vitro screening of inhibitors of angiotensin-converting enzyme (ACE), using the chromophore-and fluorophore-labelled substrate, dansyltriglycine. Planta medica. 1991 Apr;57(02):137-41

9. Engwa GA. Free radicals and the role of plant phytochemicals as antioxidants against oxidative stressrelated diseases. Phytochemicals: source of antioxidants and role in disease prevention. 2018 Nov 7:4973

10. Ghersi D, Singh M (2014) mol BLOCKS: decomposing small molecule sets and uncovering enriched fragments. Bioinformatics 30:2081-2083

11. Ghimeray AK, Jin CW, Ghimire BK, Cho DH. Antioxidant activity and quantitative estimation of azadirachtin and nimbin in Azadirachta Indica A. Juss grown in foothills of Nepal. African Journal of Biotechnology. 2009;8(13)

12. Gupta R (2004) Trends in hypertension epidemiology in India. J Hum Hypertens 18:73-78

13. Hafeez A, Askari H, Khan N, Akram M, Hanif S, Urooj N (2014) Molecular modeling of plant flavonoids as angiotensin converting enzyme (ACE) inhibitors in hypertension: A docking study. World Journal of Pharmaceutical Sciences 2(5):499-506

14. Hashmat I, Azad H, Ahmed A (2012 Oct) Neem (Azadirachta indica A. Juss)-A nature's drugstore: an overview. Int Res J Biol Sci 1(6):76-79

15. Hisle MS, Meier MS, Toth DM. Accelerating AutoDock Vina with Containerization. In Proceedings of the Practice and Experience on Advanced Research Computing 2018

16. Kaminidevi S (2015 Mar) Antimicrobial activity of methanolic extracts of indigenous traditional Indian folk Medicinal Plant, Gnaphalium polycaulon. International Journal of Green Pharmacy (IJGP) 17(1):39-44 9(

17. Kashyap M, Jaiswal V, Farooq U. Prediction and analysis of promiscuous T cell-epitopes derived from the vaccine candidate antigens of Leishmania donovani binding to MHC class-II alleles using in silico approach. Infect, Genet and Evol. 2017; 53: 107 - 15

18. Kaurinovic B, Vastag D. Flavonoids and phenolic acids as potential natural antioxidants. InAntioxidants 2019 Feb 1. IntechOpen

19. Khatua S, Ghosh S, Acharya K. A simplified method for microtiter based analysis of in vitro antioxidant activity. Asian Journal of Pharmaceutics. 2017 Apr 1;11(2):S327-35

20. Khatua S, Ghosh S, Acharya K (2017) Simplified methods for microtiter based analysis of in vitro antioxidant activity. Asian Journal of Pharmaceutics. 11

21. Kumari R, Dubey RC, Kumar S (2018) Antibacterial Efficacy of Acetone Soluble Oil of Azadirachta indica on Some Bacterial Strains. J Plant Pathol Microbiol 9(447):2

22. Laskar M, Duttachoudhury M (2014) Screening of Some Triterpenoids Isolated from Terminalia arjuna as Inhibitors of Angiotensin Converting Enzyme to Prevent Cardiovascular Diseases. Research \& Reviews: A Journal of Drug Design \& Discovery (ISSN: 2349-9036). 1. 12-19

23. Leeder S, Raymond S, Greenberg H, Liu H (2004) A race against time. The challenge of cardiovascular disease in developing economies. Columbia University, New York

24. Lloyd-Sherlock P, Beard J, Minicuci N, Ebrahim S, Chatterii S (2014) Hypertension among older adults in low-and middle-income countries: prevalence, awareness and control. International journal of Loading [MathJax]/jax/output/CommonHTML/jax.js 
epidemiology. Feb 1;43(1):116 - 28

25. Luis A, Corpas FJ, López-Huertas E, Palma JM. Plant superoxide dismutases: function under abiotic stress conditions. InAntioxidants and antioxidant enzymes in higher plants 2018 (pp. 1-26). Springer, Cham

26. Matkowski A, Tasarz P, Szypuła E. Antioxidant activity of herb extracts from five medicinal plants from Lamiaceae, subfamily Lamioideae. Journal of Medicinal Plants Research. 2008 Nov 30;2(11):321-30

27. Muhammad SA, Fatima N. In silico analysis and molecular docking studies of potential angiotensinconverting enzyme inhibitor using quercetin glycosides. Pharmacog Mag 2015; 11: 123

28. Muhammad SA, Fatima N. In silico analysis and molecular docking studies of potential angiotensinconverting enzyme inhibitor using quercetin glycosides. Pharmacognosy magazine (2015) May;11(Suppl 1):S123

29. Natesh R, Schwager SL, Sturrock ED et al (2003) Crystal structure of the human angiotensin-converting enzyme-lisinopril complex. Nature 421:551

30. Ondua M, Njoya EM, Abdalla MA, McGaw LJ. Anti-inflammatory and antioxidant properties of leaf extracts of eleven South African medicinal plants used traditionally to treat inflammation. Journal of ethnopharmacology. 2019 Apr 24;234:27-35

31. Peach MJ (1977 Apr) Renin-angiotensin system: biochemistry and mechanisms of action. Physiological reviews 57(2):313-370

32. Pescatello LS, Franklin BA, Fagard R, Farquhar WB, Kelley GA, Ray CA (2004) Exercise and hypertension. Medicine \& Science in Sports \& Exercise. Mar 1;36(3):533 - 53

33. Pettersen EF, Goddard TD, Huang CC et al (2004) UCSF Chimera-a visualization system for exploratory research and analysis. J Comput Chem 25:1605-1612

34. Rao UM, Ahmad BA, Mohd KS (2016) In vitro nitric oxide scavenging and anti-inflammatory activities of different solvent extracts of various parts of Musa paradisiaca. Malaysian J Anal Sci 20(5):1191-1202

35. Richardson DW, Wyso EM, Magee JH, Cavell GC (1960) Circulatory effects of guanethidine: Clinical, renal, and cardiac responses to treatment with a novel antihypertensive drug. Circulation. Aug 1;22(2):184 - 90

36. Sahrawat A, Sharma J (2018) Phytochemical analysis and Antibacterial properties of Azadirachta indica (Neem) leaves extract against E. coli. Journal of Pharmacognosy Phytochemistry 7(4):1368-1371

37. Septiana I, Nguyen TT, Lim S, Lee S, Park B, Kwak S, Park S, Kim SB, Kim D (2020) Enzymatic synthesis and biological characterization of a novel mangiferin glucoside. Enzyme and Microbial Technology. Mar 1;134:109479

38. Sridevi P, Prashanth KS, Bhagavan MR (2011) Angiotensin converting enzyme: A target for antihypertensive drugs. Int J Res Pharm Biomed Sc 2:63-72

39. Subapriya R, Nagini S (2005) Medicinal properties of neem leaves: a review. Current Medicinal ChemistryAnti-Cancer Agents. Mar 1;5(2):149 - 56

40. Sultana B, Anwar F, Przybylski R (2007) Antioxidant activity of phenolic components present in barks of Azadirachta indica, Terminalia arjuna, Acacia nilotica, and Eugenia jambolana Lam. trees. Food Chemistry. Jan 1;104(3):1106-14

41. Swales JD (1979 Jan) Renin-angiotensin system in hypertension. Pharmacol Ther 1(1):173-201 7( 
42. Trott O, Olson AJ (2010) AutoDock Vina: improving the speed and accuracy of docking with a new scoring function, efficient optimization, and multithreading. J Comput Chem 31:455-461

43. Tutor JT, Chichioco-Hernandez CL. Angiotensin-Converting Enzyme Inhibition of Fractions from Eleusine indica Leaf Extracts. Pharmacognosy Journal. 2018;10(1)

44. Van Bortel LM, Struijker-Boudier HA, Safar ME. Pulse pressure, arterial stiffness, and drug treatment of hypertension. Hypertension. 2001 Oct 1;38(4):914 - 21

45. Wolfender JL, Terreaux C, Hostettmann K (2000) The importance of LC-MS and LC-NMR in the discovery of new lead compounds from plants. Pharmaceutical biology. Dec 1;38(sup1):41-54

46. Basu S, Hazra B. Evaluation of nitric oxide scavenging activity, in vitro and ex vivo, of selected medicinal plants traditionally used in inflammatory diseases. Phytotherapy Research: An International Journal Devoted to Pharmacological and Toxicological Evaluation of Natural Product Derivatives. 2006 Oct;20(10):896-900

47. Srivastava P, Kasoju N, Bora U, Chaturvedi R (2009) Dedifferentiation of leaf explants and cytotoxic activity of an aqueous extract of cell cultures of Lantana camara L. Plant Cell, Tissue and Organ Culture (PCTOC). Oct 1;99(1):1

48. Khan H, Jaiswal V, Kulshreshtha S, Khan A. Potential Angiotensin Converting Enzyme Inhibitors from Moringa oleifera. Recent Patents on Biotechnology. 2019 Sep 1;13(3):239 - 48

49. Nemudzivhadi V, Masoko P. In vitro assessment of cytotoxicity, antioxidant, and anti-inflammatory activities of Ricinus communis (Euphorbiaceae) leaf extracts. Evidence-Based Complementary and Alternative Medicine. 2014; $1-8$

50. Raiola A, Del Giudice R, Monti D, Tenore G, Barone A, Rigano M (2016) Bioactive compound content and cytotoxic effect on human cancer cells of fresh and processed yellow tomatoes. Molecules 21(1):33

51. Arevalo-Híjar L, Aguilar-Luis M, Caballero-García S, Gonzáles-Soto N, Valle-Mendoza D Antibacterial and Cytotoxic Effects of Moringa oleifera (Moringa) and Azadirachta indica (Neem) Methanolic Extracts against Strains of Enterococcus faecalis. International Journal of Dentistry. 2018; 1(5)

52. Fang L, Geng M, Liu C, Wang J, Min W, Liu J (2019) Structural and molecular basis of angiotensinconverting enzyme by computational modeling: Insights into the mechanisms of different inhibitors. PloS one 14(4):0215609

53. Pierre LL, Moses MN (2015) Isolation and characterisation of stigmasterol and $\beta$-sitosterol from Odontonema strictum (acanthaceae). Journal of Innovations in Pharmaceuticals Biological Sciences 2(1):88-95

54. Khan MY, Kumar V (2019 Jan) Mechanism \& inhibition kinetics of bioassay-guided fractions of Indian medicinal plants and foods as ACE inhibitors. Journal of Traditional Complementary Medicine 9(1)(1):7384

55. Yusuf S, Sleight PE, Pogue JF, Bosch J, Davies R, Dagenais G, Heart Outcomes Prevention Evaluation Study Investigators. Effects of an angiotensin-converting-enzyme inhibitor, ramipril, on cardiovascular events in high-risk patients. The New England journal of medicine. 2000 Jan 20;342(3):145

56. Donoghue M, Hsieh F, Baronas E, Godbout K, Gosselin M, Stagliano N, Donovan M, Woolf B, Robison K, Jeyaseelan R, Breitbart RE (2000) A novel angiotensin-converting enzyme-related carboxypeptidase

Loading [MathJax]/jax/output/CommonHTML/jax.js ensin 1-9. Circulation research. Sep 1;87(5):e1-9

Page 15/25 


\section{Tables}

Table 1: $\mathrm{IC}_{50}$ value of Nitric oxide (NO) free radical scavenging activity and Superoxide $\left(\mathrm{O}_{2}^{-}\right)$radical scavenging activity

\begin{tabular}{|llll|}
\hline S.NO & Sample & $\begin{array}{l}\text { Nitric oxide }(\mathrm{NO}) \text { free radical } \\
\text { scavenging activity }\left(\mathrm{IC}_{\mathbf{5 0}}\right)\end{array}$ & $\begin{array}{l}\text { Superoxide }\left(\mathrm{O}_{\mathbf{2}}{ }^{-}\right) \text {radical } \\
\text { scavenging activity }\left(\mathrm{IC}_{\mathbf{5 0}}\right)\end{array}$ \\
\hline $\mathbf{1}$ & Azadirachta indica & 352.7473 & 269.7179 \\
\hline $\mathbf{2}$ & Moringa oleifera & 350.618 & 271.5385 \\
\hline $\mathbf{3}$ & Hibiscus sabdariffa & 317.74 & 251.8527 \\
\hline $\mathbf{4}$ & $\begin{array}{l}\text { Ascorbic acid } \\
\text { (Positive control) }\end{array}$ & 302.2222 & 243.3071 \\
\hline
\end{tabular}

Table 2: IC50 value of plant extract

\begin{tabular}{|lll|}
\hline S.No & Plants & IC $_{\mathbf{5 0}} \boldsymbol{\mu g} / \mathrm{mL}$ \\
\hline $\mathbf{1}$ & Moringa oleifera & 294.397 \\
\hline $\mathbf{2}$ & Hibiscus sabdariffa & 267.722 \\
\hline $\mathbf{3}$ & Azadirachta indica & 255.991 \\
\hline
\end{tabular}

Table 3: In silico study of isolated compounds with angiotensin converting enzyme

Table 4: Hydrogen bonding interaction of the compounds with active amino acid residues of angiotensin converting enzyme

Table 5: Toxicity Profile of the Potential Compounds (Wl: Weak inhibitor, Nl: Non-inhibitor, NT: Non-toxic, T: Toxic NC: Non-carcinogen, C: Carcinogen, HT: High toxic, LT: Low toxic, NRB: Not readily biodegradable) 


\begin{tabular}{|c|c|c|c|c|c|c|}
\hline S.No & Plant name & $\begin{array}{l}\text { Chemical } \\
\text { compounds }\end{array}$ & $\begin{array}{l}\text { Type of } \\
\text { compound }\end{array}$ & $\begin{array}{l}\text { Molecular } \\
\text { formula }\end{array}$ & $\begin{array}{l}\text { Molecular } \\
\text { weight }\end{array}$ & $\begin{array}{l}\text { Binding } \\
\text { affinity }\end{array}$ \\
\hline 1. & $\begin{array}{l}\text { Hibiscus } \\
\text { sabdariffa }\end{array}$ & Hibiscitrin & Natural & $\mathrm{C}_{21} \mathrm{H}_{20} \mathrm{O}_{14}$ & $496.4 \mathrm{~g} / \mathrm{mol}$ & $\begin{array}{l}-12.3 \\
\mathrm{kcal} / \mathrm{mol}\end{array}$ \\
\hline 2. & $\begin{array}{l}\text { Azadirachta } \\
\text { indica }\end{array}$ & Azadiradionolide & Natural & $\mathrm{C}_{28} \mathrm{H}_{34} \mathrm{O}_{6}$ & $466.6 \mathrm{~g} / \mathrm{mol}$ & $\begin{array}{l}-11.3 \\
\mathrm{kcal} / \mathrm{mol}\end{array}$ \\
\hline 3. & $\begin{array}{l}\text { Moringa } \\
\text { oleifera }\end{array}$ & Beta sitosterol & Natural & $\mathrm{C}_{29} \mathrm{H}_{50} \mathrm{O}$ & $414.7 \mathrm{~g} / \mathrm{mol}$ & $\begin{array}{l}-11.2 \\
\mathrm{kcal} / \mathrm{mol}\end{array}$ \\
\hline \multirow[t]{2}{*}{6.} & $\begin{array}{l}\text { Positive } \\
\text { control }\end{array}$ & $\begin{array}{l}\text { Enalapril } \\
\text { (standard drug) }\end{array}$ & Synthetic & $\mathrm{C}_{20} \mathrm{H}_{28} \mathrm{~N}_{2} \mathrm{O}_{4}$ & $376.453 \mathrm{~g} / \mathrm{mol}$ & $-8.1 \mathrm{kcal} / \mathrm{mol}$ \\
\hline & & $\begin{array}{l}\text { Captopril } \\
\text { (standard drug) }\end{array}$ & Synthetic & $\mathrm{C}_{9} \mathrm{H}_{15} \mathrm{NO}_{3} \mathrm{~S}$ & $217.283 \mathrm{~g} / \mathrm{mol}$ & $-5.6 \mathrm{kcal} / \mathrm{mol}$ \\
\hline
\end{tabular}

\begin{tabular}{|llllllll|}
\hline Parameters & $\begin{array}{l}\text { Human } \\
\text { Ether-a- } \\
\text { gogo- }\end{array}$ & $\begin{array}{l}\text { AMES } \\
\text { Related } \\
\text { Gene } \\
\text { Inhibition }\end{array}$ & Carcinogens & $\begin{array}{l}\text { Fish } \\
\text { Toxicity }\end{array}$ & $\begin{array}{l}\text { Tetrahymena } \\
\text { Pyriformis } \\
\text { Toxicity }\end{array}$ & $\begin{array}{l}\text { Honey } \\
\text { Bee } \\
\text { Toxicity }\end{array}$ & $\begin{array}{l}\text { Acute } \\
\text { Oral } \\
\text { Toxicity }\end{array}$ \\
\hline Beta-sitosterol & WI & NT & NC & HT & HT & HT & IV \\
\hline Hibiscitrin & WI & NT & NC & HT & HT & HT & I \\
\hline Azadiradionolide & WI & NT & NC & HT & HT & HT & III \\
\hline
\end{tabular}

\section{Figures}




\begin{tabular}{|c|c|c|c|c|}
\hline S.No & Compound & Active residues & Hydrogen Bonding length & Average bond length \\
\hline \multirow[t]{7}{*}{1} & \multirow[t]{7}{*}{ Hibiscitrin } & TYR (498) & 3.21 & \multirow[t]{7}{*}{2.9} \\
\hline & & LYS (489) & 3.24 & \\
\hline & & HIS (263) & 3.20 & \\
\hline & & TYR (358) & 3.09 & \\
\hline & & SER (260) & 2.92 & \\
\hline & & ASN (263) & 2.95 & \\
\hline & & GLY (254) & 2.71 & \\
\hline \multirow[t]{3}{*}{2} & \multirow[t]{3}{*}{ Azadiradionolide } & THR (144) & 3.00 & \multirow[t]{3}{*}{2.6} \\
\hline & & ASN (263) & 2.80 & \\
\hline & & ASN (145) & 3.09 & \\
\hline \multirow[t]{4}{*}{3} & \multirow[t]{4}{*}{ Beta sitosterol } & TYR (372), & 2.70 & \multirow[t]{4}{*}{2.8} \\
\hline & & ASP (366), & 3.01 & \\
\hline & & HIS (388), & 3.09 & \\
\hline & & GLY (382) & 2.74 & \\
\hline \multirow[t]{2}{*}{13} & \multirow[t]{2}{*}{ Captopril } & ARG (522) & 1.75 & \multirow[t]{2}{*}{2.1} \\
\hline & & GLU (411) & 2.85 & \\
\hline \multirow[t]{2}{*}{14} & \multirow[t]{2}{*}{ Enalapril } & TYR (523) & 2.55 & \multirow[t]{2}{*}{2.7} \\
\hline & & HIS (353) & 2.87 & \\
\hline
\end{tabular}
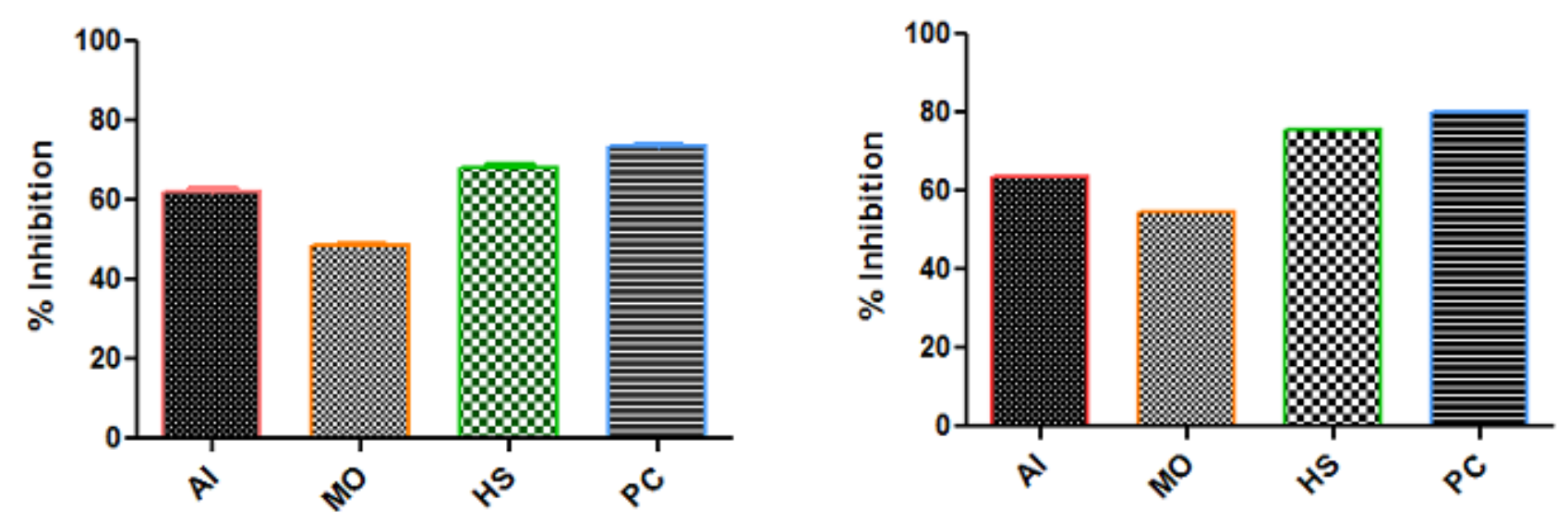

\section{A}

\section{Figure 1}


A) percentage inhibition of nitric oxide B) percentage inhibition of SOD

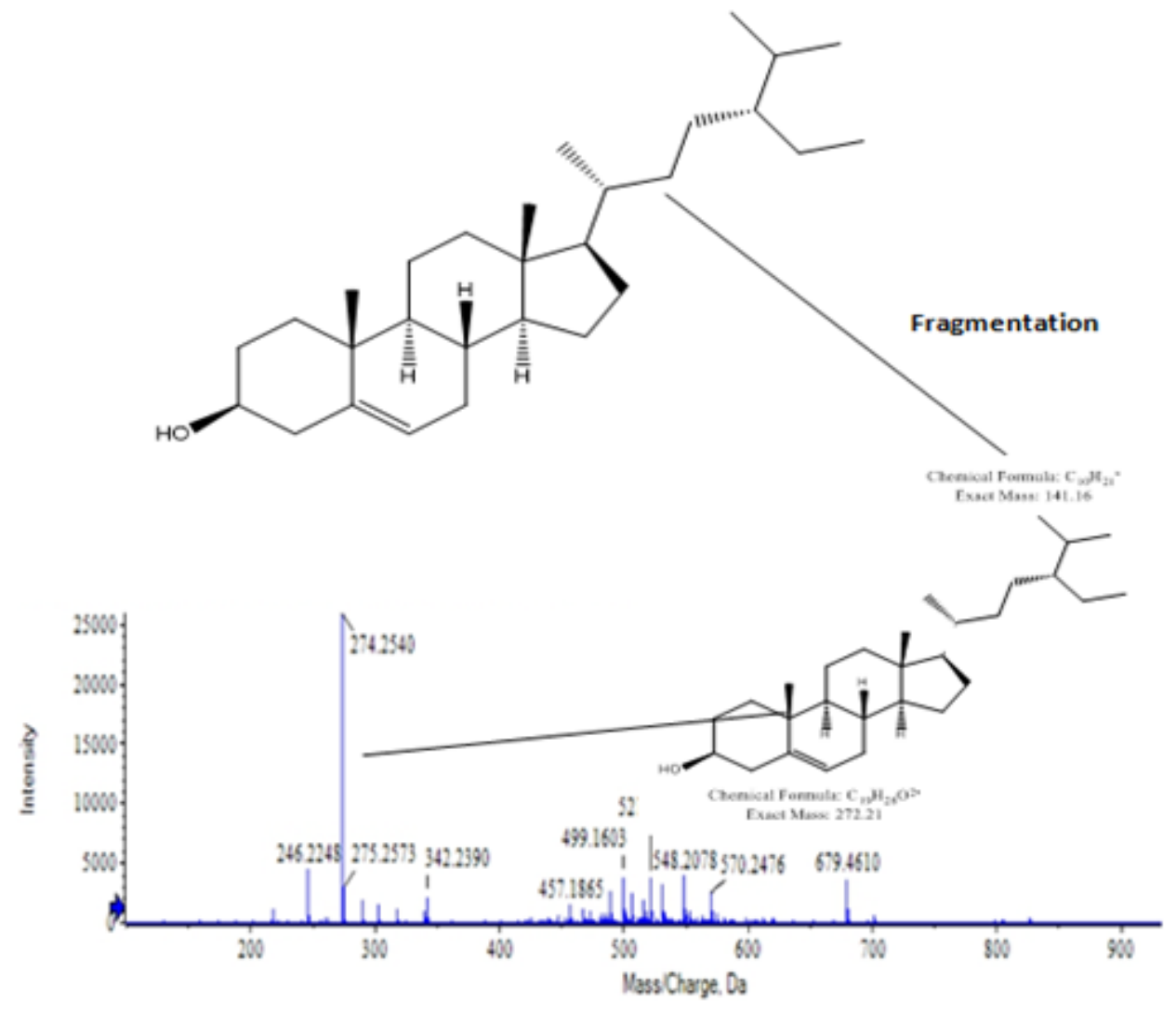

Figure 2

Mass spectrum of different chromatographic peaks of Moringa oleifera fraction 


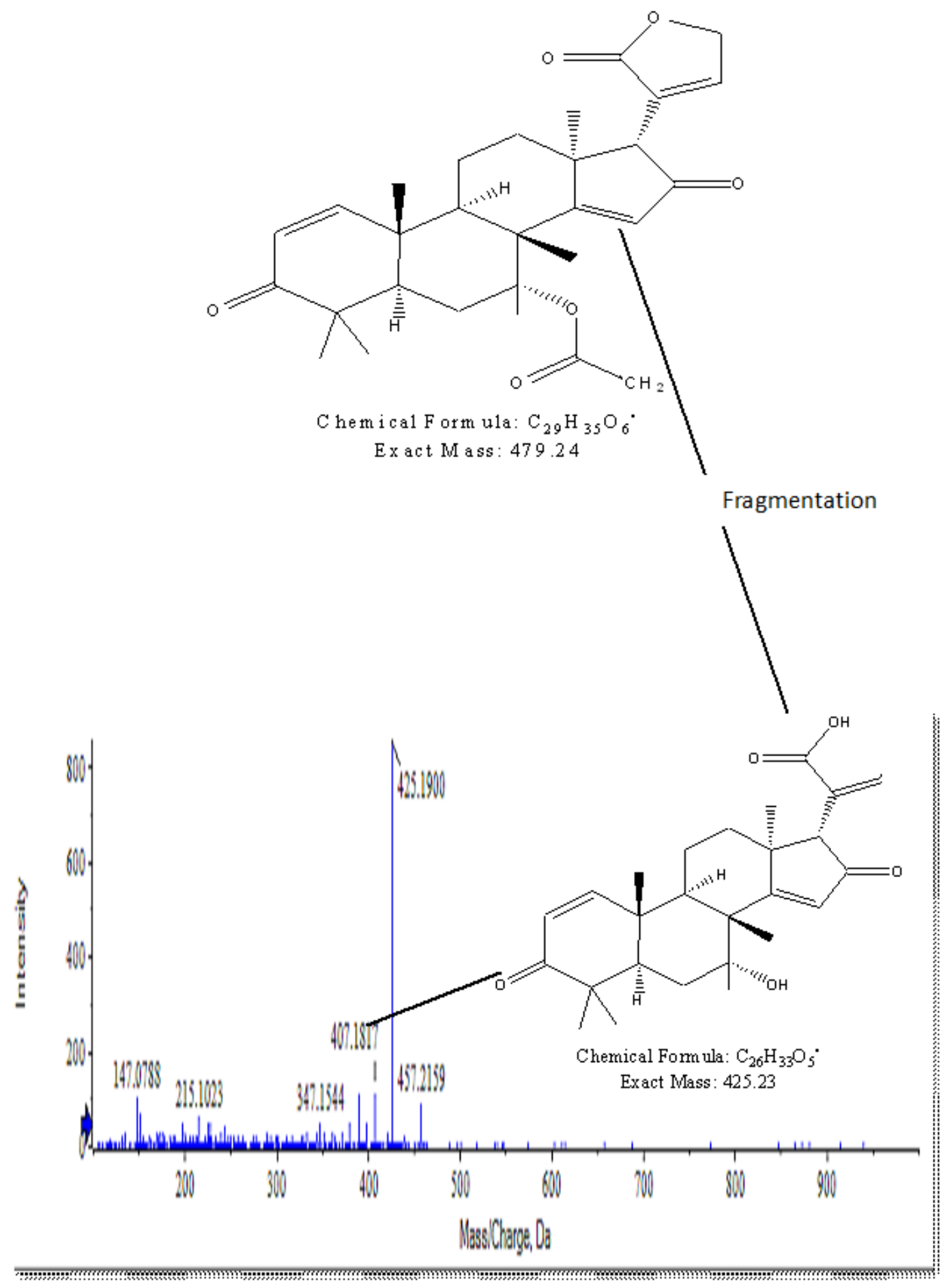

\section{Figure 3}

Mass spectrum of different chromatographic peaks of Azadirachta indica fraction 


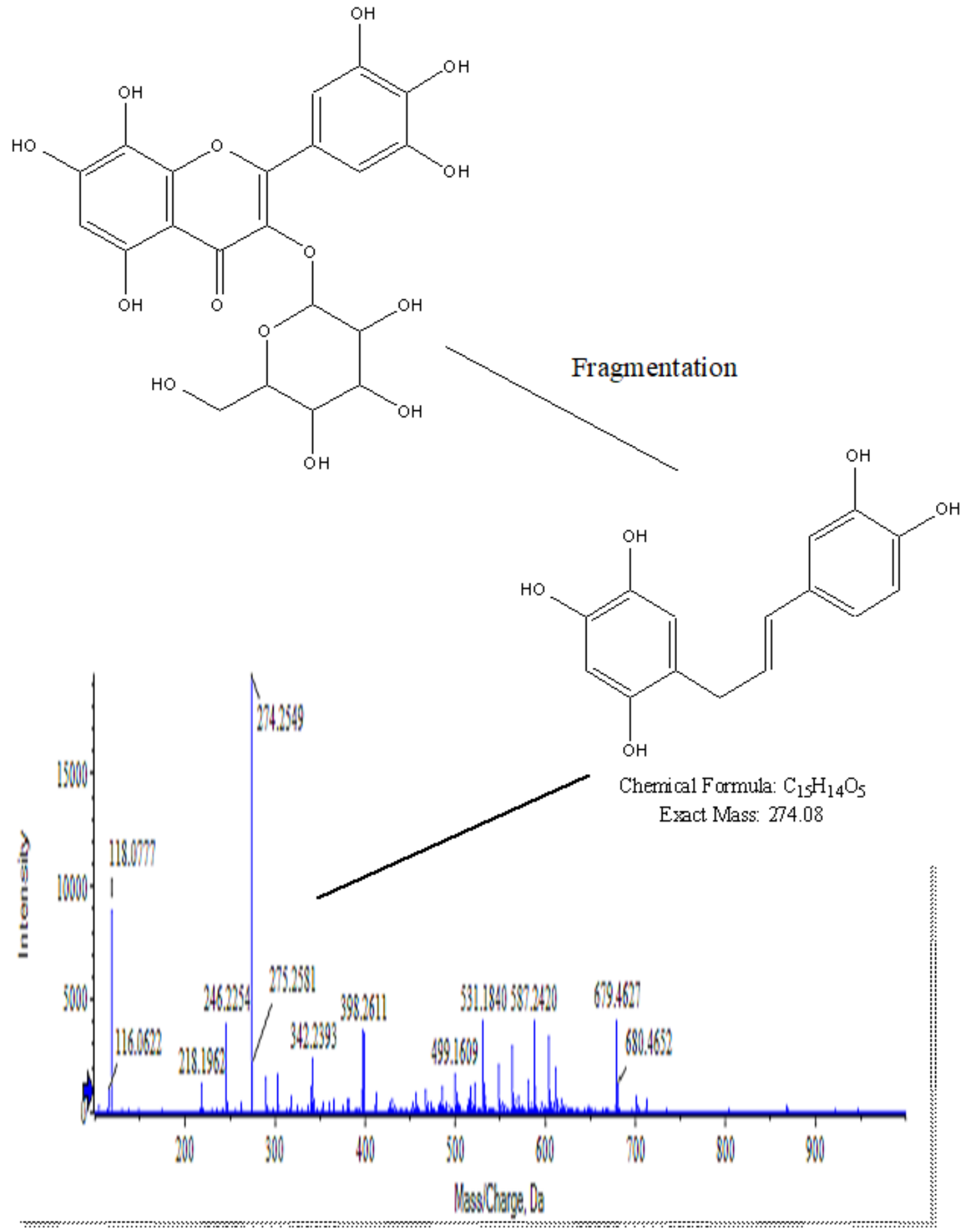

Figure 4

Mass spectrum of different chromatographic peaks of Hibiscus sabdariffa fraction 


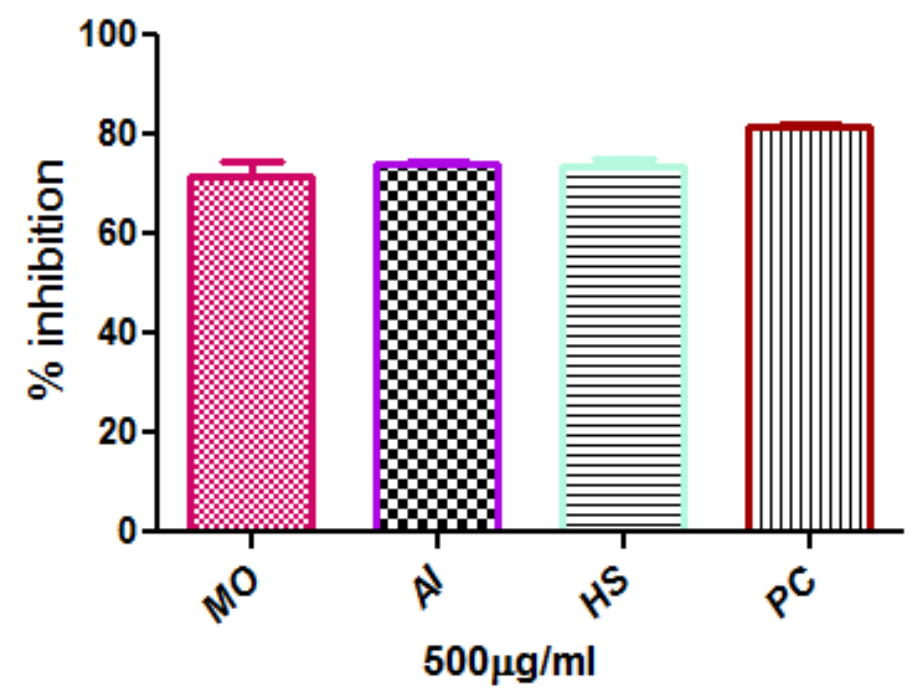

Figure 5

Percentage inhibition of Moringa oleifera MO, Azadirachta indica (Al), Hibiscus sabdariffa (HS), and Positive control (PC)
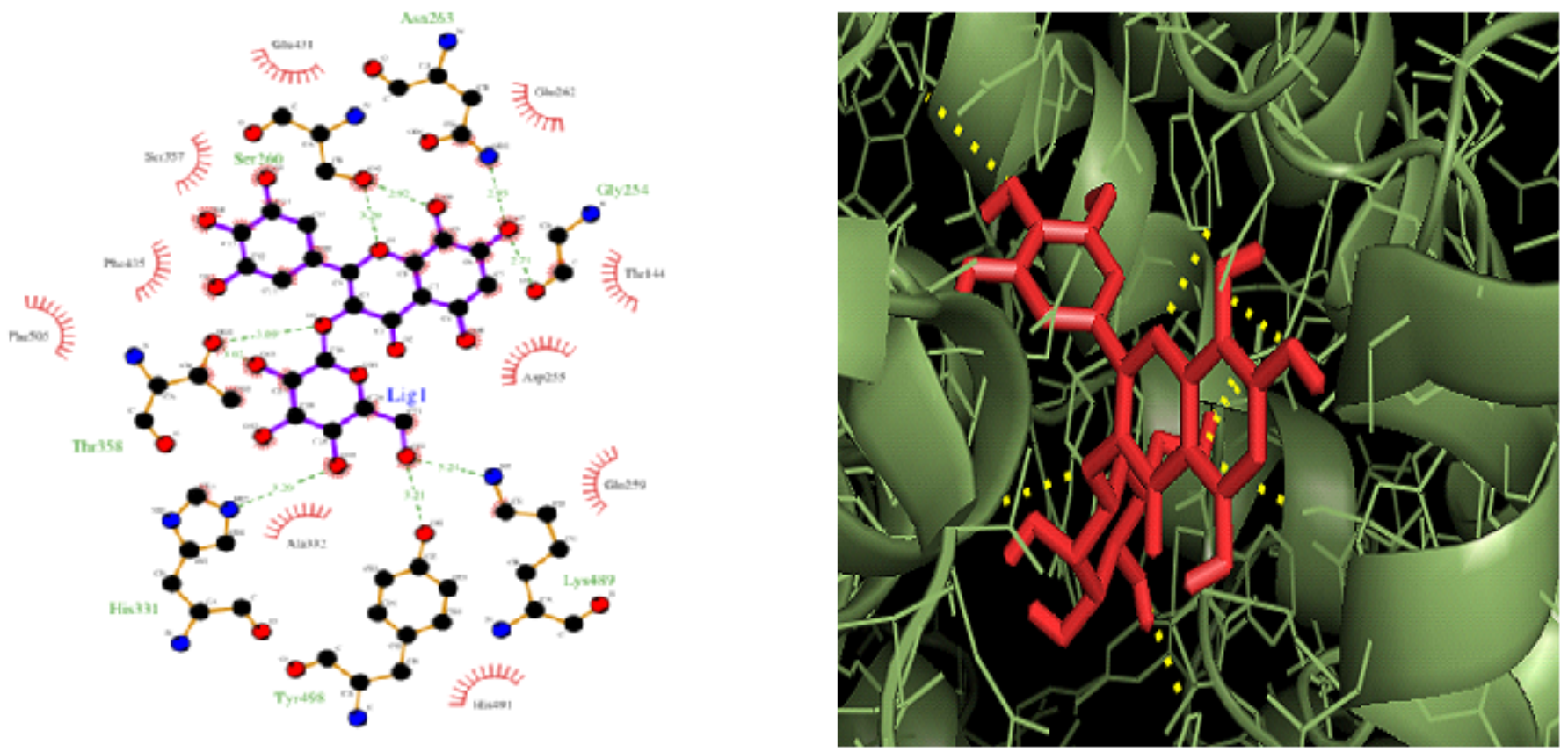

Figure 6

Ligplot of Hibiscitrin ligand from Hibiscus sabdariffa fraction with active amino acid residue of ACE 

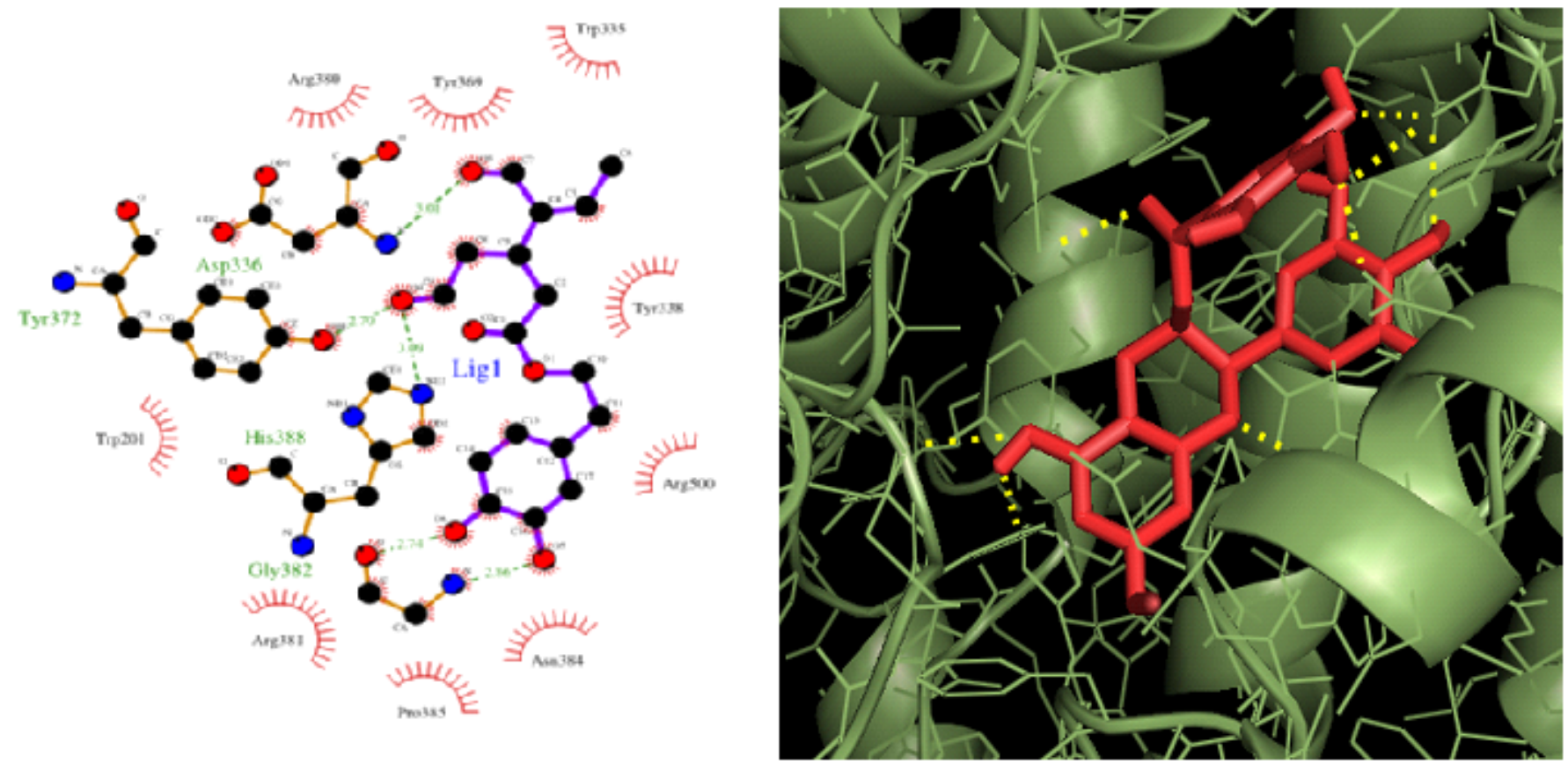

Figure 7

Ligplot of beta sitosterol ligand from Moringa oleifera fraction with active amino acid residue of ACE
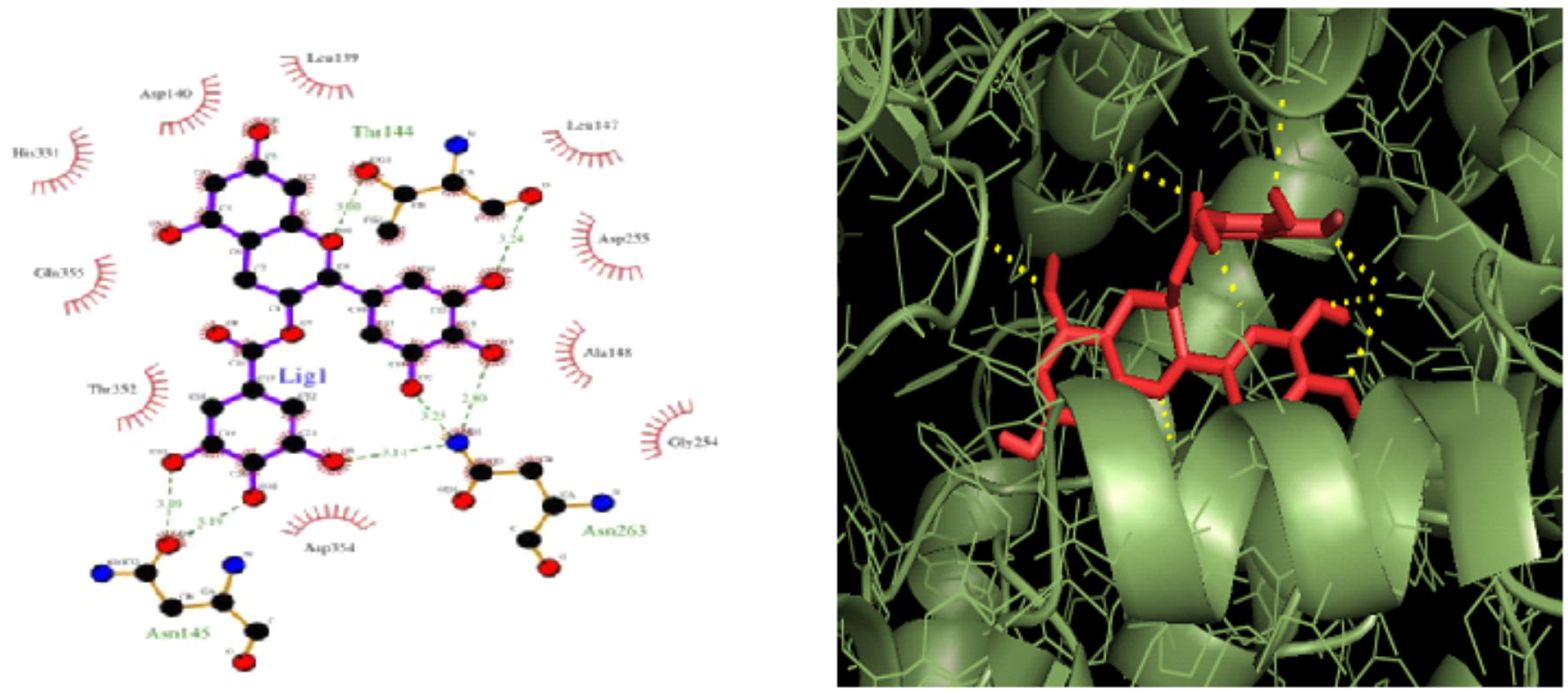

Figure 8

Ligplot of Azadiradionolide ligand from Azadirachta indica fraction with active amino acid residue of ACE 


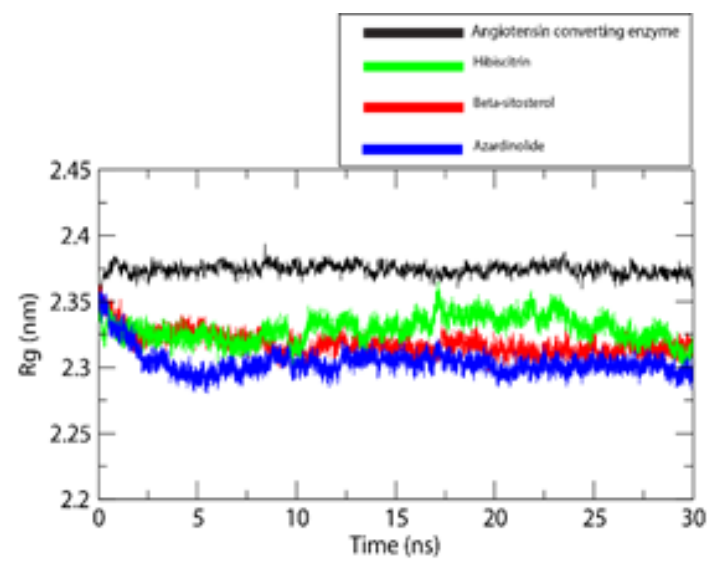

\section{A}

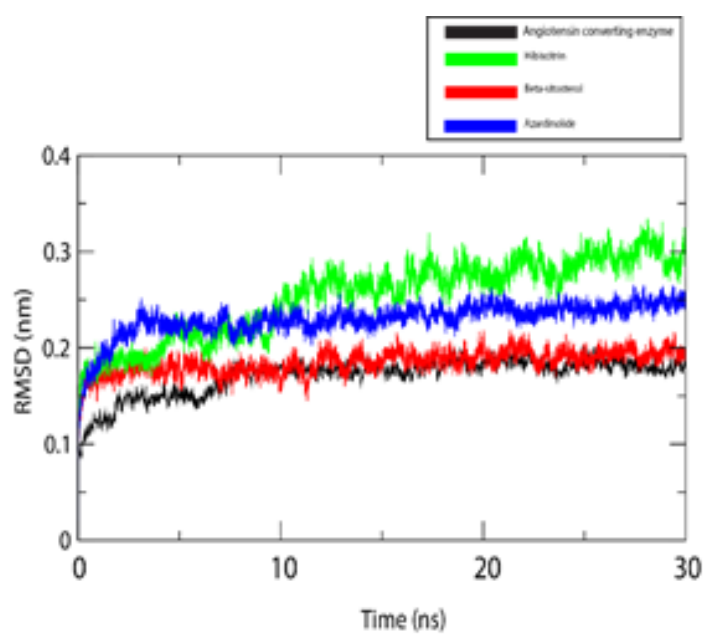

$\mathrm{B}$

\section{Figure 9}

Radius of gyration, RMSD analysis of ACE and bioactive compounds over 30ns simulation

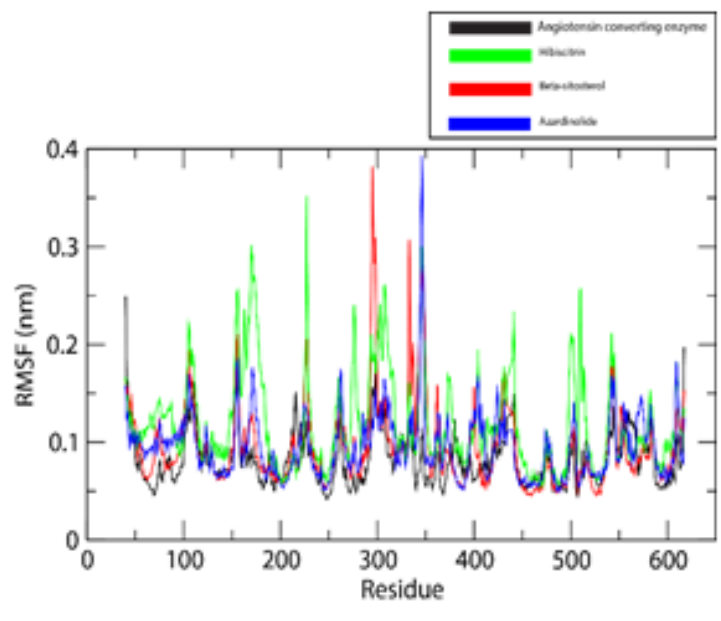

A

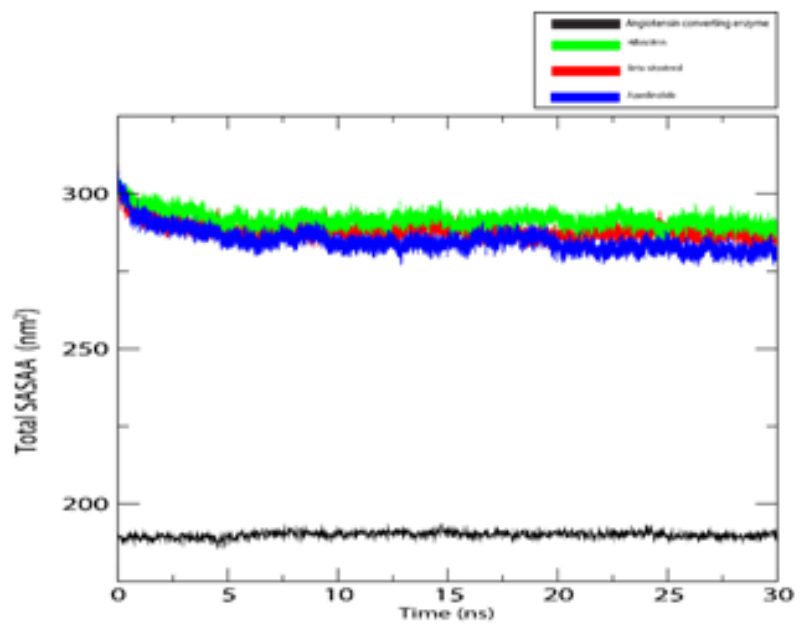

B

\section{Figure 10}

RMSF of ACE with active amino acid residues and SASA of ACE and bioactive compounds over 30ns 


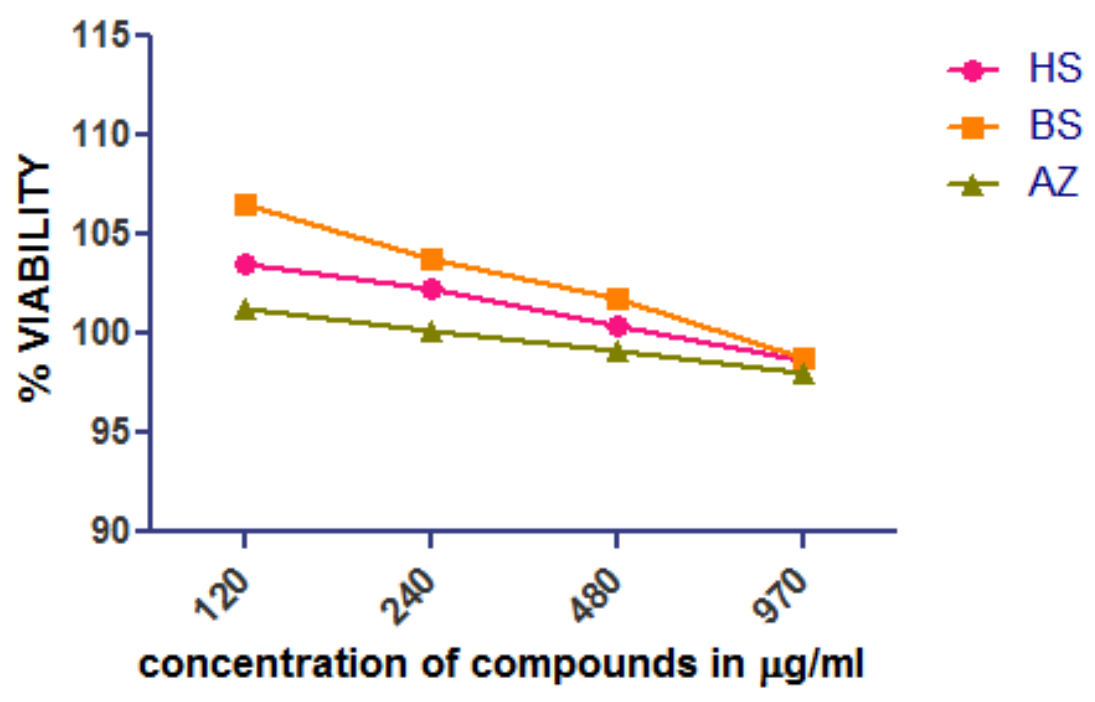

Figure 11

Percentage viability of the compounds Hibiscitrin (HS) beta-sitosterol (BS), and Azadiradionolide (AZ)

\section{Supplementary Files}

This is a list of supplementary files associated with this preprint. Click to download.

- supplementryfile.docx 